\title{
China's International Poverty Reduction Center as a Platform for South-South Learning
}

\section{BY ZHONG WU, PHIL KARP, AND YAN WANG}

AFTER ATTENDing a South-South experience-sharing event in China, a number of African officials wondered: "How come China is able to develop and retain its implementation capacity, whereas our countries suffer from brain-drain?"

The short answer is that China has institutionalized a learning process to capture lessons from its own development experience and that of others. To this end, the International Poverty Reduction Center in China (IPRCG) was set up to serve as a plat- form for South-South learning and capacity development. Established in 2005 by the Government of China, IPRCC is supported by a number of international organizations including UNDP, the World Bank, the UK Department for International Development, and the Asian Development Bank. IPRCG was conceived at the Global Conference on Scaling Up Poverty Reduction held in Shanghai in 2004. Soon after, at the United Nations 6oth Anniversary Summit on Development Funding, Chinese President Hu Jintao announced that "the International Poverty - Reduction Center in China (IPRCC) was established in Beijing

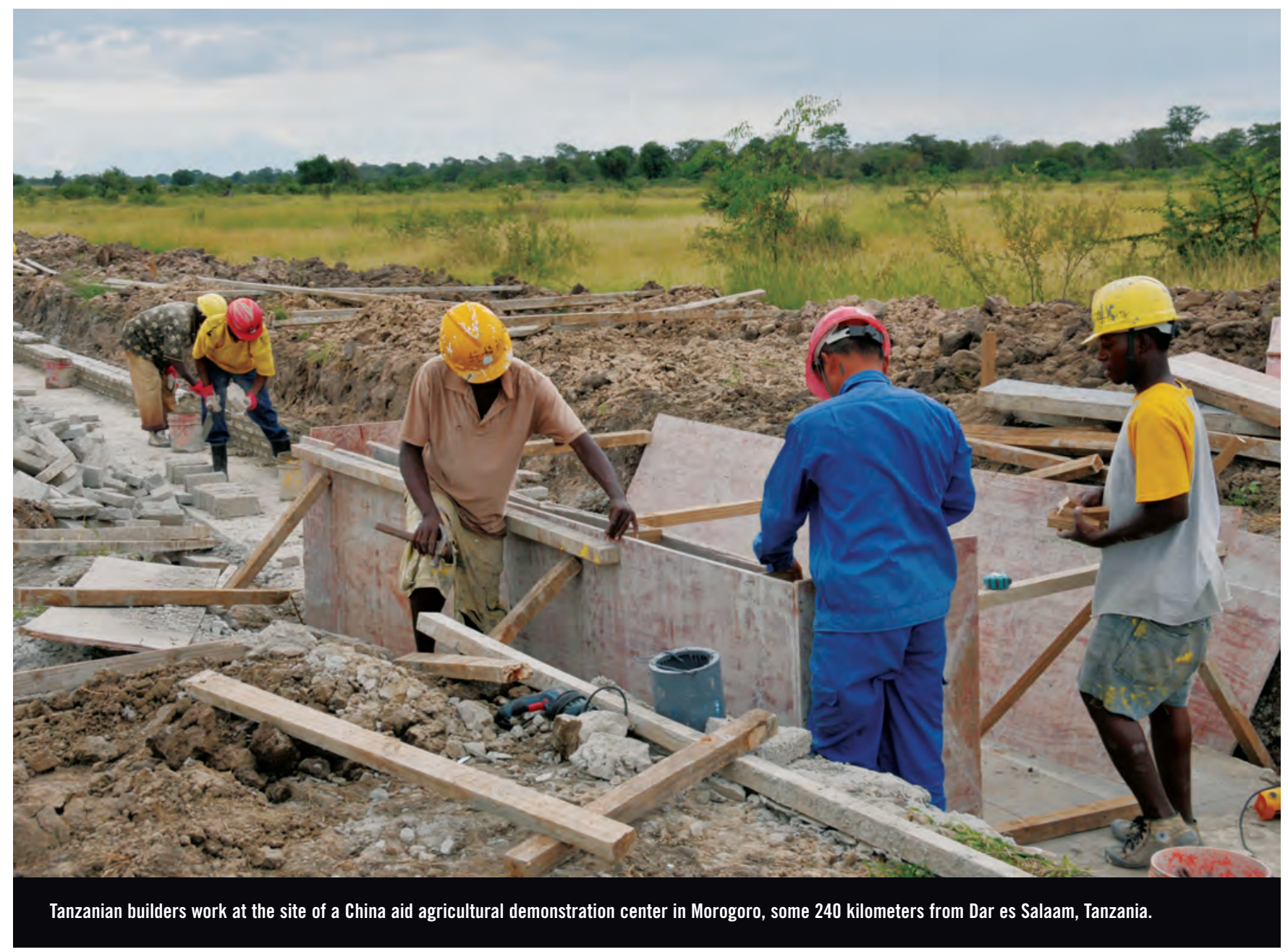


FIGURE 1: IPRCC AS A PLATFORM FOR SOUTH-SOUTH LEARNING AND COOPERATION

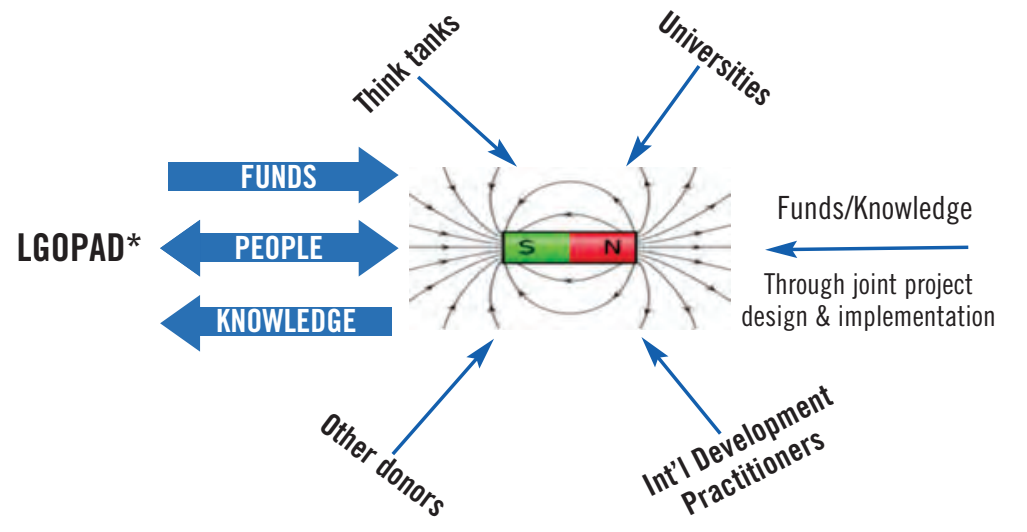

${ }^{*}$ Leading Group of Poverty Alleviation and Development Source: Authors.
Economic Zones (SEZs), and Township and Village Enterprises and then developing capacity through learning-bydoing. Only in a later stage were modern institutions adopted, such as the laws and regulations required by the World Trade Organization (WTO) principles. China took pragmatic approaches based on the experience of countries that were closer to its own stage of development, at the time of the opening-up process. So SEZs, for example, were adopted from Hong Kong, Taiwan, and Singapore's experience in the early 1980s, but adapted to China's own characteristics. After difficult initial stages in its own development process, China is now wellplaced to contribute to global poverty reduction by sharing its

with a mission to make contributions to the global poverty reduction." The IPRCC has since become one of the flagship organizations in China for South-South cooperation and has represented China in several international fora including the Task Team on South-South Cooperation and the associated High Level Event on South-South Cooperation, in Bogota, Colombia.

Why is IPRCC becoming such an important platform for South-South learning? To this question we need to understand IPRCC's role in a broader context (Figure 1).

First, IPRCC's credibility is rooted in China's rapid development and poverty reduction that took place in the span of one generation, and which have been an inspiration to other developing countries. When China started its reform 3o years ago, it faced tremendous uncertainty. No one knew the specific path to the envisaged "end model." No one expected that in the three decades following the initiation of pro-market reforms in 1978, China would achieve the most rapid poverty reduction in human history. Using the new international poverty line of $\$ 1.25$ a day in 2005 purchasing power parity (PPP), it is estimated that in the 24 years after 1981, over 635 million people in China were lifted out of poverty and the proportion of the population living in poverty fell from 84 percent to 16 percent (Chen and Ravallion 2008). ${ }^{1}$ Naturally, policymakers and development practitioners would very much like to understand what has worked in China, why, and how.

Second, the IPRCG was established with the firm belief that learning from countries that are in similar stages of development can be more relevant than learning from highly advanced countries, especially in the early stages. This is partially because capable institutions cannot be imported or created overnight. China's experience points to the efficacy of first developing home-grown and second-best institutions such as the Household Responsibility System, Special rich and diverse experiences at various stages of development.

Third, IPRCG benefits from the significant attention and resources that the Chinese government devotes to South-South cooperation, serving as an important window for South-South learning and experience sharing. The Chinese government has invested heavily in training and technical assistance programs for officials from other developing countries, particularly in Africa. IPRCC's activities are a part of this bigger picture.

Fourth, IPRCG has a unique governance structure and institutional setup, involving a range of important domestic and international partners. Nationally, IPRCG falls within the administrative structure of China's State Council, but with links through its board of trustees to the National Development and Reform Commission, Ministry of Finance, Ministry of Commerce, and Ministry of Foreign Affairs. On the international side, it is supported by the World Bank, UNDP and other international donors, and has succeeded in attracting world renowned experts including several Nobel Laureates as its senior advisors.

Fifth, IPRCG is an attractive knowledge resource for development practitioners around the world, especially those from Africa. In the last five years, IPRCG has provided training to nearly 600 officials and development practitioners (see Table 1). It has developed a unique approach to training and experience-sharing, which it implements with local and international partners, including the World Bank. The typical model involves workshops in Beijing where participants are able to interact with government officials and researchers, followed by week-long field visits to the poor regions and coastal areas. Since development practitioners come from countries with varying socioeconomic backgrounds, they have a range of needs and interests. By organizing field visits to different parts of the country, IPRCG can satisfy a range of learning 
needs covering various sectors and levels of government. IPRCC training programs address not only general knowledge about China's development experience, but also specific institutional approaches (for example, farmer water-user associations, microfinance, disaster management, and community-driven development). Participants can witness with their own eyes, the "what" and "how" of China's development.

Sixth, the IPRCG is becoming a center of excellence for South-South learning, attracting talent from the government and academic sectors, including top universities and research institutes. One of the reasons that China can build and retain implementation capacity is that officials in organizations like IPRCG remain a part of the system and therefore benefit from stable career development opportunities. At the same time, the fast-growing Chinese economy and dynamic development of enterprises and institutions have attracted new talent.

\section{Challenges and implications for South-South Cooperation}

DELIVERING on the South-South Cooperation Agenda will depend on the development of effective institutions, including those of the state, the parastate, the private sector, and civil society. The uneven development performances across countries are largely determined by the quality of institutions, which ultimately shape incentives for learning, experimentation, and entrepreneurship.

Therefore, we need dynamic institutions like IPRCC that can attract talent at home and abroad, and serve as platforms and facilitators for South-South learning. However, IPRCG is still a young organization with limited in-house capacity for conducting research and producing training materials that meet the needs of diverse groups of development practitioners. It needs to invest in staff capacity and to bring in international expertise, especially on issues such as development effectiveness, monitoring and evaluation, and impact assessment. This should not be done in isolation, since capacity can best be developed through mutual learning and knowledge exchange. Hence IPRCG is using mechanisms such as visiting scholar programs, and staff exchange programs with multilateral and bilateral institutions and other development think tanks.

IPRCG embodies many of the ideas and principles of the "Bogota process" in which it was an active participant. It is very much a Southern-led institution, but one which welcomes and leverages the experiences and resources of other partners, while retaining its own unique characteristics. It seeks to promote mutual respect and win-win outcomes with its partners. IPRCC also firmly recognizes that South-South learning and sharing of knowledge and experience for countries in all phases of development is key to capacity development.

We believe that IPRCC offers a useful institutional model that is relevant to other countries. Indeed it is our firm view that the emergence of a network of flexible institutions, like IPRCG, that effectively analyze and document their own countries' experiences and share these through South-South learning would make a significant contribution to poverty reduction and to sustainable capacity development.

Zhong Wu is Director General of the International Poverty Reduction Center in China (IPRCC).

Philip Karp is a Lead Specialist at the World Bank Institute. Yan Wang is a Senior Economist at the World Bank Institute.

\section{Endnote}

1 Chen, Shaohua and Martin Ravallion. 2008. "China is poorer than we thought, but no less successful in the fight against poverty," World Bank Policy Working Paper no 4621, page 11.

\section{TABLE 1: RAPID GROWTH OF IPRCC SINCE ITS ESTABLISHMENT, 2005-2010}

\begin{tabular}{|c|c|c|c|c|c|c|c|}
\hline & 2005 & 2006 & 2007 & 2008 & 2009 & $2010^{*}$ & Total \\
\hline $\begin{array}{l}\text { Number of training programs for Int'I Development } \\
\text { Practitioners }\end{array}$ & 1 & 2 & 2 & 7 & 5 & 4 & 23 \\
\hline $\begin{array}{l}\text { Number of international participants in IPRCC's training } \\
\text { programs }\end{array}$ & 53 & 64 & 80 & 144 & 152 & 97 & 590 \\
\hline Number of international conferences organized by IPRCC & & 2 & 3 & 3 & 4 & 4 & 16 \\
\hline Number of participants in international conferences & & 200 & 600 & 610 & 790 & 440 & 2640 \\
\hline RESEARCH/PUBLICATIONS: & & 3 & 3 & 4 & 22 & 37 & 69 \\
\hline Books in Chinese & & 3 & 3 & 4 & 10 & 7 & 27 \\
\hline Books in English & & & & & 2 & 4 & 6 \\
\hline Papers in Chinese & & & & & 10 & 21 & 31 \\
\hline Papers in English & & & & & 0 & 5 & 5 \\
\hline
\end{tabular}

